\title{
GHOSTS OF GHOSTS
}

\author{
By Nina Auerbach
}

What hope of answer, or redress?
Behind the veil, behind the veil.

In Memoriam 56, 11. 27-28

WELL, NOT EXACTLY. Tennyson was disingenuous, if reverent, when he proclaimed that denizens of the afterlife were darkling things, flitting suggestively behind nature's veil. In fact, most Victorian ghosts were aggressively lifelike; they had little interest in sequestering themselves behind the veil, but an omnivorous hunger for the familiarity they had supposedly left behind. Arthur Conan Doyle, who endured decades of derision for his crusading Spiritualist faith, found only the living in the dead: "I have seen my mother and my nephew, young Oscar Hornung, as plainly as I ever saw them in life - so plainly that I could almost have counted the wrinkles of the one and the freckles of the other," he insisted valiantly (qtd. in Stashower 347).

Far from subsiding into mystic gleams, ghosts were often more prosaically present than the living. The Oxford Book of Victorian Ghost Stories, edited by Michael Cox and R. A. Gilbert, is full of sturdy spirits, as in Mary Louisa Molesworth's "The Story of the Rippling Train," whose revenant "had nothing insubstantial about it. She had looked to me, as she stood there, literally and exactly like a living woman - the shade of her dress, the color of her hair, the few ornaments she wore, all were as defined and clear as yours" (324). In Algernon Blackwood's "The Kit-Bag," bad men are as corporeal as good women. "Not three feet from him the man [a cruel murderer] stood, the fringe of black hair marked plainly against the pallor of the forehead, the whole horrible presentment of the scoundrel, as vivid as he had seen him day after day in the Old Bailey" (488). True, shadows slither among these anthologized ghosts, but a shadow presupposes a solid substance lurking somewhere, even if we cannot see it.

Ghosts may seem to elude serious scholars except as metaphor or atmosphere, but there is a surprising abundance of books about them. Individually, these books may look as weird as ghosts themselves. Together, though, they resurrect the Victorian dead in all the range and rage of their tenacious lives.

Like ghosts themselves, ghost books fall into categories ranging from denial to fixation. The most interesting books, to me at least, explore Victorian ghosts to uncover the scarcely less surreal powers and taboos that composed that spectral abstraction, Victorian womanhood. Diana Basham, Vanessa D. Dickerson, and Karen Beckman believe in ghosts because they 
believe in the women who, denied citizenship, cultivated supernatural attributes by which they were both enervated and energized. Basham, Dickerson, and Beckman are serious about their spectral studies, though I doubt whether gender-neutral ghosts would have attracted them; theirs are the ghosts of social mythologies.

Then there are the Spiritualists, for whom ghosts of any sex or sort take precedence over humanity. In Spiritualist writing, of which reams have been produced between the nineteenth and twenty-first centuries, we are interesting only after we die; once vividly dead, we become worthy of obsessed attention. Spiritualism is one of the many Victorian religions that still flourishes, not only in clannish New Age cults, but in popular movies like The Sixth Sense which features a Wordsworthian boy who sees dead people and teaches the allegedly living to see them too; he never needs to acquire the "humanheartedness" towards which Wordsworth's otherworldly youngsters were supposed to evolve.

Today's Spiritualism is not just for children, or for women, who in this century seem to have better things to do than ghost-seeing. Cable television features a battle between famous male mediums: abrasive John Edwards squares off against soothing James Van Praagh. Both men transmit only the happy dead; as in the nineteenth century, the living exist only as conduits to an afterlife reassuringly close to the life we know. Unlike media mediums, contemporary Spiritualist Hilary Evans, a scientifically-minded believer, refuses to burble over his ghosts, teasing out their contradictory lives in the true spirit of Victorian empiricism. I feature his book, Seeing Ghosts, because it fascinates me in its willingness to be boring, its austere refusal to frighten or console us.

I suspect that most of my readers, like myself, have never communicated with ghosts; we know them through movies and fiction. The serious scholarship on ghosts in fiction and film is, however, surprisingly sparse. Ghosts are usually excluded from surveys of horror movies - I suspect because no one can decide whether they are monsters or angels - though some talented film critics write about ghosts in isolation from other scary creatures. Literary critics have edited innumerable anthologies of Victorian ghost stories, but these attract little critical attention: either the critics use ghosts as a fulcrum for other issues (usually the condition of women) or individual ghosts disappear in sonorous generalizations. Julian Wolfreys's recent Derrida-infused Victorian Hauntings claims to read various canonical texts as ghost stories (In Memoriam, Little Dorrit, The Mayor of Casterbridge), but Wolfreys is so addicted to opaque abstractions, and to non-words like "phantomize" and "spectrality," that the particularity of his material evaporates; he can only conclude that "all stories are, more or less, ghost stories" (3) or that "haunting [is] a condition of all narrative" (139). So much for the eccentric effervescence of nineteenth-century apparitions. I can find no one who has built upon Jack Sullivan's lovely 1978 study, Elegant Nightmares: The English Ghost Story from LeFanu to Blackwood. Sullivan takes ghosts seriously, but as his subtitle acknowledges, his short book is narrow in scope. Perhaps Victorianists are still too frightened of ghosts (or ghostly attraction) to become the Spiritualist readers the subject demands.

\section{Womanly Ghosts}

DiANA BASHAM's The Trial of Woman and Vanessa D. Dickerson's Victorian Ghosts in the Noontide are eerily complementary. Basham rousingly reveals the occultism that inspired Victorian feminism in its prophetic mode; Dickerson evokes the enforced liminality of both Victorian women and ghosts. 
The Trial of Woman is so learned and alive that it is not, strictly speaking, a ghostly book. Like the flesh-and-blood women who are its subjects, it finds inspiration in female prophets from Ada Byron to Helena Blavatsky. Claiming that occult experience - trance, mesmerism, séances, and supernatural fiction - infused women's sphere in Victorian England and finally inspired that ultimate triumphant abstraction, the New Woman, Basham, like the best feminist critics, resurrects previously embarrassing material with triumphant elan.

The best chapter is the last, a bravura commemoration of Helena Blavatsky. Weaving Blavatsky's odd life in and out of paranoid male fiction about mighty women (Rider Haggard's She and Disraeli's Lothair, along with Disraeli's own florid self-creating life), Basham shows Blavatsky both inspiring literary mythology and creating herself from it. As Basham tells the story, Blavatsky triumphed because she inspired the New Woman as depicted in Elizabeth Robbins's ephemeral novel The Convert. I think, though, that becoming Madame Blavatsky is triumph enough. Blavatsky may have been a trickster who wrote incomprehensible prose, but she founded a religion - Theosophy - that lives throughout the world today. Whether or not we are Theosophists, we all know the unforgettable photograph of her large face brooding out at us. Few prophets, and no feminists, remain as instantly recognizable as Madame Blavatsky. The New Woman, if she ever existed, could scarcely match the power of that presence.

Like many writers about the occult and other weird topics, Basham tends to justify her material by politicizing it. Most of the time, I think she is right; it is fascinating to learn that in the 1850s, Lady Byron, who was enthralled by mesmerism and Spiritualism, joined Elizabeth Blackwell, Barbara Leigh-Smith, and some American mediums at a séance. "Barbara LeighSmith emerged from the darkened rooms of the Spiritualist séance with a clear sense of her own future direction and immediate goal: the establishment of Langham Place as a campaigning center for Women's Rights, and the writing of her 1854 dissertation" on laws concerning women (21); Elizabeth Blackwell, the first woman doctor, found her vocation during a mesmeric trance. This marriage of occultism and reform should not be surprising; suppressed by conventional religion, we take inspiration where we find it or make it. But mesmerism and Spiritualism would be worth studying as alternative faiths even if Barbara Leigh-Smith and Elizabeth Blackwell had not gone on to justify occultism politically.

Basham's examples do not have quite the historical resonance of Barbara Goldsmith's magnificent Other Powers, an account of Victoria Woodhull's meteoric career that weaves a stunning tapestry of the convergence of Spiritualism, feminism, and free love in nineteenthcentury America. Goldsmith reminds us incidentally that Elizabeth Cady Stanton composed at a spirit table the Women's Declaration of Rights and Sentiments she delivered at Seneca Falls in 1848. American historians are now, perhaps grudgingly, commemorating Stanton's Seneca Falls declaration (her table reposes in the Smithsonian), but I wish they would commemorate her spirits as well. Basham may dilute the power of the spirits by yoking them to secular success stories. She surely dilutes the fear women inspire by yoking it to primordial fears of menstruation. By the evidence of her own material, women are frightening enough; our powers need not be explained away as masks for hidden hormones.

Vanessa D. Dickerson is more plaintive than Basham. She too extracts the spectral essence of Victorian womanhood, but her women are not incendiary; deprived of citizenship, relegated to spiritual supremacy, they float between worlds. "It was mete that woman give up, rein in, be silent, be still. She was to fulfill her role by disappearing into the woodwork to watch over the household" (4). The more a woman is good, the more she is a ghost, "a figure of indeterminacy, of imperiled identity, of substance and insubstantiality" (5). Dickerson's 
ghosts are not very frightening, but they materialize in beautiful prose. Like Terry Castle in her moving account of the shadowy half-life of lesbians, The Apparitional Lesbian: Female Homosexuality and Modern Culture, Dickerson summons ghosts, not to frighten authority, but to mourn enforced invisibility.

Basham's and Dickerson's ghost stories bestow on Victorian women the double nature of all ghosts. Are they frightening or pathetic? Emissaries of death, some come boldly to appall us; others flaunt their lost lives only to lament. The analogy between living women and the restless dead makes for two uncommonly illuminating books, but ironically, women's affinities with ghosts tell us more about life than about literature.

Both Basham and Dickerson move uneasily from society to fiction. Both try, too schematically and in too short a space, to discuss Victorian ghost stories as distinctively female, which they are not. Ghost fiction was, often, stereotypically associated with woman writers, but so, at various times, were prosy domesticity, moral superiority, moral turpitude, and just about everything else. Victorian literature, by men and women alike, cannot shake its hauntedness. Even leaving aside Dickens's Christmas ghost stories or Henry James's and Thomas Hardy's artfully obsessed spectral play, most famous literature by men, obsessed with a vanishing past, is apparitional in its essence. I find Robert Browning's volume Men and Women far more ghostly than Aurora Leigh, the best-selling verse novel by his Spiritualist wife Elizabeth. Officially, Robert Browning despised Spiritualism, but his best poems raise the ghosts of the Italian Renaissance, making its obscure citizens walk, talk, see, and think their Renaissance thoughts, while Aurora Leigh is aggressively contemporary. Elizabeth Barrett Browning, who claimed to believe in ghosts, rudely shucks off the past as literary material; her characters are all newly-minted; while for Robert, the ostensible unbeliever, only the dead are imaginatively alive.

There is no reason to claim ghost stories as women's property. Cox and Gilbert's anthology, The Oxford Book of Victorian Ghost Stories (which actually ends in 1908), has twelve stories by women and twenty-one by men, plus two "anons." These proportions might seem skewed, especially since the anthology's publicity sheet boasts that "this selection emphasizes the key role played by women writers." In fact, though, with the exception of Margaret Oliphant and Vernon Lee, whose stories are uncommonly long, Cox and Gilbert do include the requisite canonical women (Gaskell, Rhoda Broughton, Dinah Craik, Amelia Edwards, Edith Nesbit, and so on), while omitting eminent men like Oscar Wilde, whose "Canterville Ghost" is one of the funniest extant elegies for the scene-stealing Victorian ghost, and H. G. Wells, whose "The Red Room" is one of the scariest stories I have ever read. Ghosts saturated Victorian men; by the Edwardian decade male writers had appropriated them entirely. Probably something could be made of the distinctiveness of women's ghost stories, though this is a more vexed topic than we might want it to be, but while Victorian ghosts did cling to disenfranchised women, who as a result might have lived with them in greater comfort than men did, to be haunted in the nineteenth century was to be human.

Both Basham and Dickerson search women's ghost stories for distinctively female plots, but these prove as elusive as ghosts themselves. Ghost stories are fiendishly difficult to generalize about; formulaic though they are, they tend to be willfully inconclusive, lacking the obsessed single-mindedness that makes the best nineteenth-century novels cohere despite their great length. And there are so many of them! Basham runs into trouble when she acknowledges that premier writers like Charlotte Riddell, Amelia Edwards, and Vernon Lee - as well as Margaret Oliphant in her much-anthologized "The Open Door" - deal almost 
exclusively with male ghost-seers. Edwards and Lee do sometimes let women perform as alluring phantoms, but ghost experiences are almost always reserved for men. Some of the bestknown female writers of the twentieth century - Daphne du Maurier, Pat Barker, and Susan Hill in The Woman in Black - similarly empathize with shattered, ghost-seeing men, not with ghostly or ghost-like women. What does this mean? Are women's ghosts vehicles of satire, exposing the terrors within supposedly powerful men? Or are they an escape from the ghosted perspective that is supposedly inherent in womanhood? Basham never raises these questions, which threaten to undermine the alliance she insists on between women and the occult.

Dickerson, too, seems not to know what to say about women's ghost stories. She falls into predictable oppositions, claiming not that men did not write ghost stories, but that their ghosts are authoritative and hegemonic, while women's embody the pain of exclusion: "It was finally not men's but women's ghost stories that truly treated the return of the repressed and the dispossessed; ghost stories could provide a fitting medium for eruptions of female libidinal energy, of thwarted ambitions, of cramped egos" (8). Ghost stories certainly could provide such a medium, but I am not sure they do. Instead of trying to generalize about an overwhelming amount of material, at once formulaic and eccentric, Basham and Dickerson might better have traced the ghosts of a particular woman writer. My candidate would be the oddly ignored Rhoda Broughton.

Like most Victorian writers - and unlike the specialists who were to come in the next century, such as Shirley Jackson or Stephen King - Broughton did not make her career from ghosts: "the queen of the circulating library," known for her risqué and sensuous novels, wrote ghost stories on the side. Her major collection, alternatively titled Twilight Stories and Tales for Christmas Eve, is uncommonly hard to find, but unlike better-known stories by Amelia Edwards, Vernon Lee, and the rest, Broughton's collection adheres to woman's experience. Moreover, it is cumulatively frightening. Its most familiar story, "Poor Pretty Bobby," is the sexiest and the sweetest spectral love story I know; "The Man With the Nose" is the most nightmarish haunted honeymoon; in its account of the preternatural power of a mind awry, "Behold It Was A Dream!" is an extraordinary forerunner of twentieth-century horror. Broughton does everything feminist critics want women's ghost stories to do - they show the horror and pain lurking in ordinary female experience - and yet she is scarcely discussed.

I suspect critics ignore her because her women do not fit the Victorian mold we have constructed; they are neither self-consciously assertive nor crushed; instead, they are bilious sophisticates. Broughton's well-off women are usually grumbling about something, often travel, always other people. The narrator of "Under the Cloak" finds in train travel, not a jolly Dickensian spectacle of teeming characters, but a nightmare of intimacy: "I hate and dread exceedingly a crowd, and would much prefer at any time to miss my train rather than be squeezed and jostled by one" (90). Broughton's ghost-seeing women are too urbane to be called Victorian as we want to understand the word, but biliously contemporary as they seem, they do embody the power of Basham's occult and the alienation of Dickerson's disenfranchisement.

Victorian ghost stories have a way of resisting our beliefs. They raise the same tricky questions ghosts themselves do: do revenants confirm religious dogma, proving that there is reunion and an afterlife, or do they make nonsense of spiritual solemnity with their triviality, the incoherence of their appearances, their perverse remarks? Just as ghosts should tell us something about immortality, ghost stories by women should tell us something about women's suppressed condition. Maybe they do, and we are too opaque to understand it. $^{2}$ 
Literature being trickier than life, the new academic fashion of Cultural Studies should unravel more definitively the kinship between ghosts and Victorian women. Karen Beckman's Vanishing Women: Magic, Film, and Feminism is one of the most appealing recent books I have read. Beckman's focus, on which her book plays virtuoso variations, is the popular 1880s magic act in which a magician makes his female assistant disappear. Like most works of Cultural Studies, Vanishing Women says virtually nothing about literature but a lot about popular culture and twentieth-century film: her book moves from the Indian Mutiny to spirit photographs to 1890s ghost films to Hitchcock's The Lady Vanishes, ending grandly with four Bette Davis portrayals of fading stars. Like most such works, Vanishing Women is full of great nuggets - there are wonderful analyses of Malthus and single women, and of the several meanings of "ectoplasm" (I never knew it was both the Spiritualist term for ghost-substance and an image projected on a screen) - but as with most Cultural Studies texts, the parts are better than the whole. A ghostly woman reposes at the center of Beckman's book, its point being that the vanishing woman is the most potent presence in all these works. Surely this is so when Bette Davis plays her, but though Vanishing Women tells us about a lot of things, it does not answer the questions Basham and Dickerson raise about Victorian women and ghosts: before exploring its material it gallops on to the next clever analogy. In their way, all three accounts of spectral women skirt the contradictions of fiction. We may get a clearer perspective if we put both women and literature aside and look more carefully at ghosts alone.

\section{Spiritualism}

SPIRITUALISM, the science of communication with the dead, is constantly derided but it refuses to die. Like evolution, psychoanalysis, Communism, sociology, and gynecology, Spiritualism is a Victorian creation that haunts us still. For believers, communion with the dead is the essence of life; power, oppression, theatricality, sexuality, art, pale before the allure of the world beyond. In Victorian England, talking to the dead was so popular, if often so pitiful, that in 1882 the Society for Psychical Research came into being to separate reality from fraud. Its aim was, and is, scientific: it authorizes valid ghosts and weeds out deceivers. With Arnoldian high seriousness and Darwinian empiricism, ignoring literature, religion, or other fanciful effusions of hope and fear, the SPR tells us which ghosts we may live with.

Hilary Evans, according to his book jacket, is a member of the SPR who has twice served on its Council. On the face of it, his Seeing Ghosts has nothing to do with Victorian England; it records sightings from all centuries, though they tend to be monotonously alike; but the high seriousness with which Evans analyzes his data - a series of truncated tales all of which come from the archives of the SPR - his self-mortifying refusal to profess complete faith in the apparitions that obsess him, are eminently Victorian in their essence.

Seeing Ghosts is, moreover, Victorian at its source. For Evans and most of his Spiritualist colleagues, ghosts are not a symptom of social, religious, or romantic unease; ghost-seeing is an experience all its own, self-contained and self-complete. Ghosts may not have much to tell us, but they deserve our full attention. The integrity of Evans's somewhat blinkered realism has its origin in a particular Victorian woman whom Seeing Ghosts respectfully acknowledges: the Spiritualist martyr Catherine Crowe, whose meticulous transcriptions of others' spirit-encounters brought her notoriety and, eventually, isolation and insanity. 
Crowe's The Night-Side of Nature, Or, Ghosts and Ghost-Seers appeared in 1848, at the very beginning of the Spiritualist vogue, thirty-four years before the founding of the SPR it helped inspire. Crowe was the first to write about ghosts, not as spooks, Christmas spirits, moral exempla, or occult avatars, but as scientific phenomena. Crowe, like Evans, is relentlessly anti-theoretical; like Evans's, her ghosts take brief shape in a compendium of fleeting encounters by some anonymous narrator. Crowe's "Madame O- B-" makes an ideal companion for Evans's "Miss M. C., Hertfordshire, England, 1866." Crowe's ghosts, like her ghost-seers, are discontinuous presences who bob up and vanish, sometimes for no reason, sometimes to warn of a dire event, often to say a cryptic goodbye at the moment of death. They are generally earthly, not celestial, demonic, or alien figures. Crowe defines indelibly the Victorian ghost in all its restricted worldliness: "[Ghosts] appear as they lived and as they conceive of themselves" (298). For Catherine Crowe in 1848 as for Hilary Evans in 2002, ghosts are as vivid and pointless as life is itself. They are in fact so alive that there seems to be no point in studying them.

Most monsters mutate with their times, but our own ghosts, both those of literature and science, cling intractably to Victorian visions. At the turn of the twenty-first century, ghost stories like Susan Hill's The Lady in Black or inspirational American movies like The Lady in White or Ghost possessed their audiences because they were defiantly anachronistic; their ghosts promised, not progressive advance, but the resurrection of a seemingly lost past. They return bringing reassurance, not enlightenment.

Because ghosts are inextricable from what we already know, they are usually excluded from surveys of popular monsters. David Skal's wonderful, and seemingly comprehensive, The Monster Show, and, more recently, Darryl Jones's bright and breezy survey, Horror, are cozily at home with ghouls, giant insects, werewolves, and vampires, but they make no mention of ghosts, who presumably are neither monstrous nor horrifying, remaining within the boundaries of the normal - though of course if ghosts were fully un-monstrous they would be merely us. Some cinematic ghosts have been segregated in their own books, such as Gary J. and Susan Svehla's subtle if obscure critical anthology Cinematic Hauntings, but books about cinematic ghosts tend to be as much nostalgic paeans to the lost art of black-and-white film-making as they are accounts of ghosts in themselves. Ghosts, it seems, cannot thrive without battening on what we already know, or imagine we once knew: they are not quite monsters, nor are they quite familiar. The books they inspire are almost always illuminating and even moving, capturing a wealth of subjects but leaving alone the ghosts at their heart.

University of Pennsylvania

\section{NOTES}

1. If the elusive F. G. Loring turns out to be a woman, the numbers shift slightly to thirteen stories by women and twenty by men. I know Loring only as the author of a luridly derivative vampire story called "The Tomb of Sarah" - not properly a ghost story, though Cox and Gilbert unaccountably include it whose female vampire is so revolting a schlurper that I assume the author was male. Cox and Gilbert include some good, subtly scary stories, but they provide no material on the authors, neglecting even to identify the many who use only cryptic initials.

2. Mediumship was a great career for Victorian women, though there was nothing distinctively female about it. Ann Braude and Alex Owen have written penetrating accounts of women as mediums in 
nineteenth-century America and England respectively. Since Braude and Owen are historians whose books are almost fifteen years old, they do not technically belong in this survey, but their books remain unsurpassed accounts of the social collaboration between women and ghosts.

\section{WORKS CONSIDERED}

Basham, Diana. The Trial of Woman: Feminism and the Occult Sciences in Victorian Literature and Society. New York: New York UP, 1992.

Beckman, Karen. Vanishing Women: Magic, Film, and Feminism. Durham and London: Duke UP, 2003.

Braude, Ann. Radical Spirits: Spiritualism and Women's Rights in Nineteenth-Century America. Boston: Beacon, 1989.

Broughton, Rhoda. Twilight Stories (Tales for Christmas Eve). 1873. London: Home \& Van Thal, 1947.

Castle, Terry. The Apparitional Lesbian: Female Homosexuality and Modern Culture. New York: Columbia UP, 1993.

Cox, Michael, and R. A. Gilbert, eds. The Oxford Book of Victorian Ghost Stories. Oxford and New York: Oxford UP, 1992.

Crowe, Catherine. The Night-Side of Nature, Or, Ghosts and Ghost-Seers. 1848. Northamptonshire, UK: Aquarian, 1986.

Dickerson, Vanessa D. Victorian Ghosts in the Noontide: Women Writers and the Supernatural. Columbia and London: U of Missouri P, 1996.

Evans, Hilary. Seeing Ghosts: Experiences of the Paranormal. London: John Murray, 2002.

Goldsmith, Barbara. Other Powers: The Age of Suffrage, Spiritualism, and the Scandalous Victoria Woodhull. New York: Knopf, 1998.

Jones, Darryl. Horror: A Thematic History in Fiction and Film. London and New York: Oxford UP, 2002.

Owen, Alex. The Darkened Room: Women, Power and Spiritualism in Late Victorian England. Philadelphia: U of Pennsylvania P, 1990.

Skal, David J. The Monster Show: A Cultural History of Horror. New York: Norton, 1993.

Stashower, Daniel. Teller of Tales: The Life of Arthur Conan Doyle. New York: Henry Holt, 1999.

Sullivan, Jack. Elegant Nightmares: The English Ghost Story from LeFanu to Blackwood. Athens, Ohio: Ohio UP, 1978.

Svehla, Gary J., and Susan, eds. Cinematic Hauntings. Baltimore: Midnight Marquee, 1996.

Wolfreys, Julian. Victorian Hauntings: Spectrality, Gothic, the Uncanny, and Literature. Hampshire, UK: Palgrave, 2002. 